\title{
Thermal evolution of ladder-like silsesquioxanes during formation of black glasses
}

\author{
Piotr Jeleń $^{1}$ (1) $\cdot$ Magdalena Szumera $^{1} \cdot$ Magdalena Gawęda $^{1} \cdot$ Elżbieta Długoń $^{1}$ • \\ Maciej Sitarz ${ }^{1}$
}

Received: 24 November 2016/Accepted: 2 March 2017/Published online: 10 March 2017

(C) The Author(s) 2017. This article is published with open access at Springerlink.com

\begin{abstract}
Pyrolysis of ladder-like silsesquioxanes in oxygen-free atmosphere leads to the formation of silicon oxycarbides (black glasses). Black glasses are materials of amorphous silica structure where some amount of $\mathrm{O}^{2-}$ ions were replaced by $\mathrm{C}^{4-}$ ions. This exchange leads to local increase in bonds density and therefore improvement in mechanical, thermal, and chemical properties. Thanks to this modification, silicon oxycarbide glasses can be used in a variety of applications like: protective coatings and interconnectors in solid oxide fuel cells. Xerogels were prepared by sol-gel method, and ladder-like silsesquioxanes were used as precursors. Samples were burned at $200-1000{ }^{\circ} \mathrm{C}$ in inert atmosphere. Structural studies in the middle infrared range (MIR) and SEM with EDX confirmed the presence of SiOC bonds in obtained materials. MIR analysis of solid samples together with TG/dTG measurements allowed defining the process for the formation of black glasses.
\end{abstract}

Keywords Silsesquioxanes · FTIR - Thermogravimetry · Black glasses

\section{Introduction}

Black glasses are ceramic materials where some part of $\mathrm{O}^{2-}$ ions are exchanged for $\mathrm{C}^{4-}$ ones. Therefore, these materials feature both $\mathrm{SiO}_{2}$ and $\mathrm{SiC}$ bonds. This leads to

Piotr Jeleń

pjelen@agh.edu.pl

1 Faculty of Materials Science and Ceramics, AGH University of Science and Technology, Mickiewicza 30, 30-059 Kraków, Poland the strengthening of glass structure and enhancement of its properties, i.e., chemical, thermal, and oxidation resistance [1-4]. Two main concepts of silicon oxycarbide structures exist. First one states that free carbon phase is distributed inside $\mathrm{SiO}_{2}$ glassy matrix, while the second one states that amorphous silica is closed inside graphite/graphene network $[5,6]$. In our previous work, we tried to describe the formation of free carbon phase in silicon oxycarbide glasses pyrolized at temperature ranging from 200 to $800{ }^{\circ} \mathrm{C}$ [7]. Many routs can be employed to achieve black glasses [7-10]. Depending on desired outcome-final product properties, a variety of preceramic materials with different function groups can be used-like methyl, ethyl, and vinyl [11-14]. Changing the precursor can lead to formation of different black glasses, e.g., materials with or without free carbon phase [5, 7, 15, 35]. From the variety of possible applications, at least few should be mentioned, i.e., anodes for Li-ion batteries [16], material for artificial heart valves [17], and protective coatings [4]. Most of the research focuses on two temperature ranges used to obtain SiOC glasses-below $400{ }^{\circ} \mathrm{C}$ for low-k thin layers and above $1000{ }^{\circ} \mathrm{C}$, where phase separations occurs $[4,10]$. In our work we focus on obtaining fully amorphous silicon oxycarbide materials that can be obtained below $1000{ }^{\circ} \mathrm{C}$.

Aim of this work is to track, with the usage of TG and MIR studies, the formation of black glasses obtained from methyl terminated ladder-like silsesquioxanes of different $\mathrm{Si} / \mathrm{O} / \mathrm{C}$ ratios.

\section{Experimental}

The MTES- $\mathrm{CH}_{3} \mathrm{Si}\left(\mathrm{OCH}_{3}\right)_{3}$ ( $T$ units) and DMDES$\left(\left(\mathrm{CH}_{3}\right)_{2} \mathrm{Si}\left(\mathrm{OC}_{2} \mathrm{H}_{5}\right)_{2}\right)(D$ units) were used as a silsesquioxane precursors $[11,22,23]$. Three mixtures of $T / D=1 / 1$, 
Fig. 1 Thermogravimetric and first derivative (dTG) curves of analyzed $T / D$ mixtures

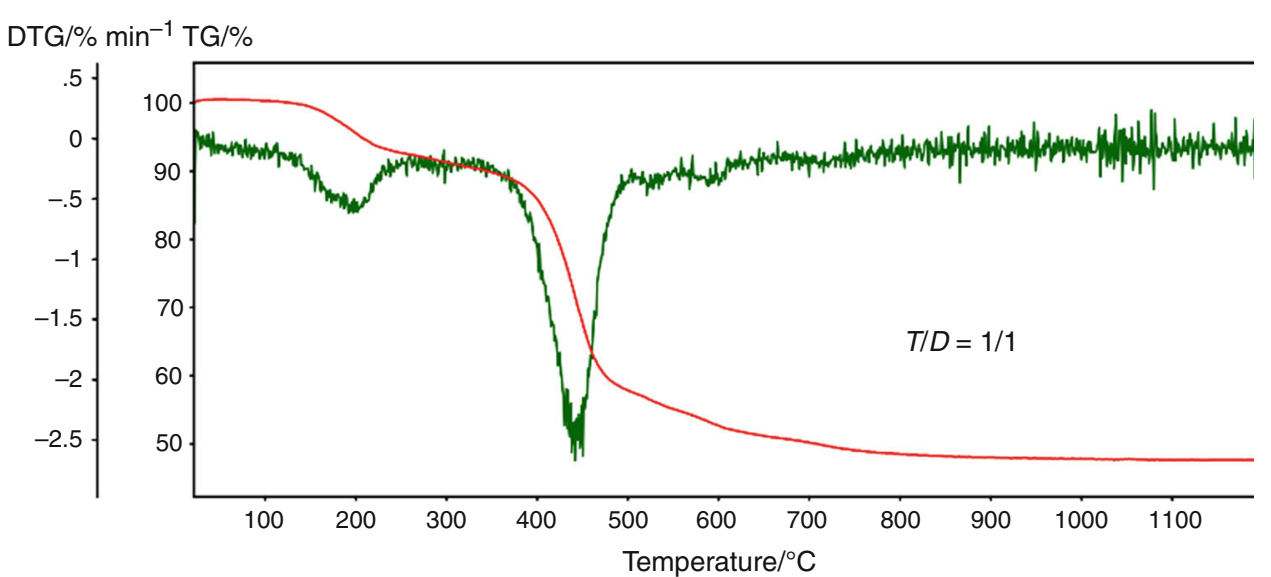

DTG/\% $\min ^{-1}$ TG/\%

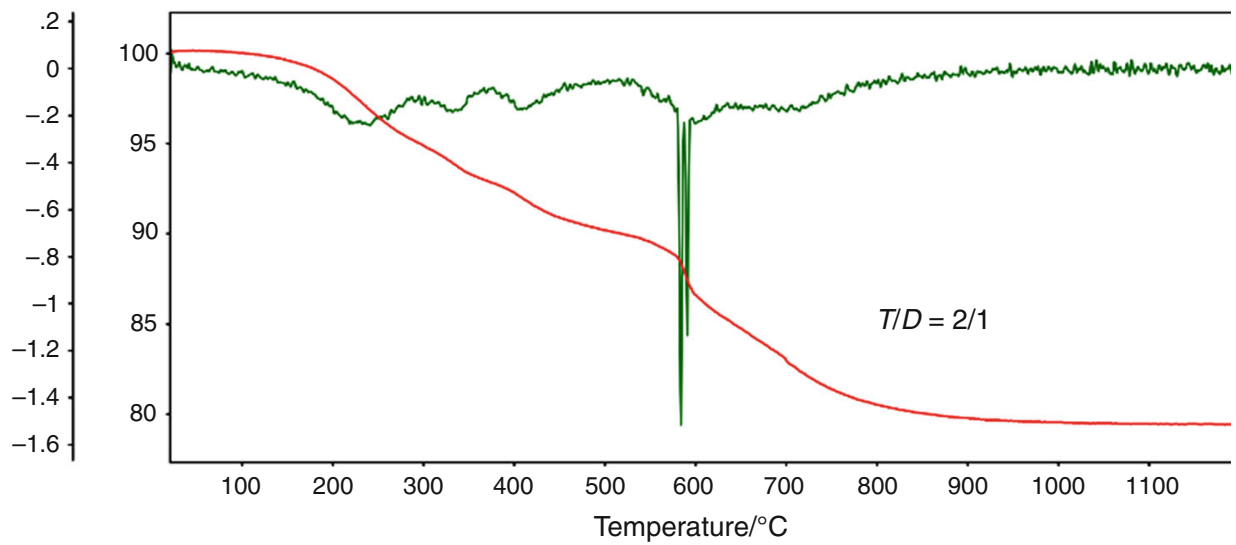

DTG $/ \% \min ^{-1} \mathrm{TG} / \%$

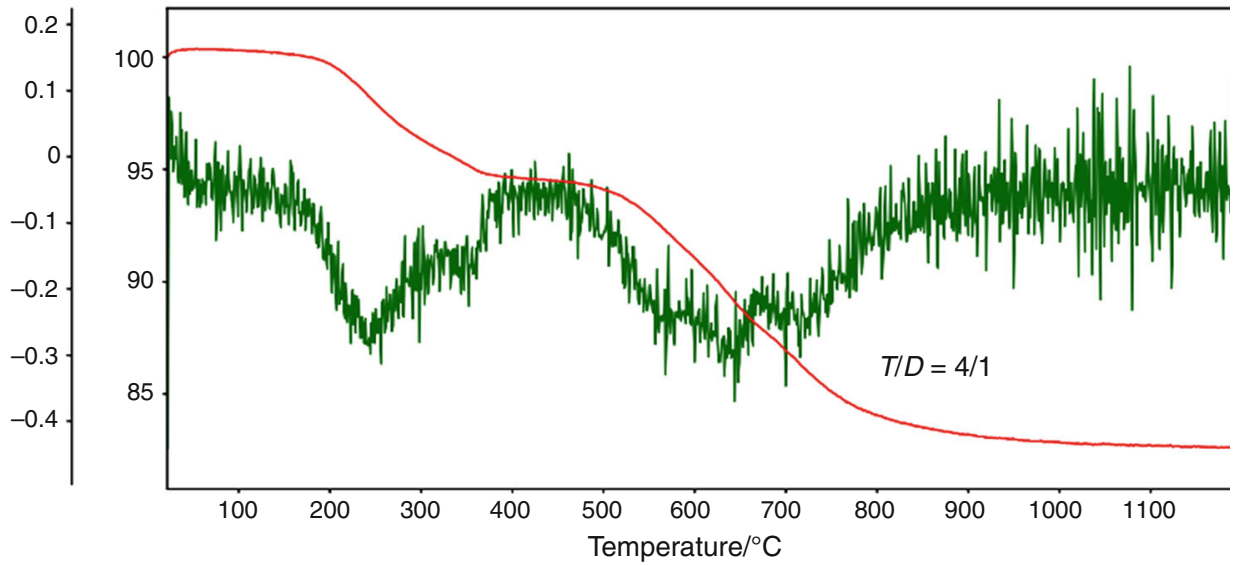

Table 1 Mass loss during pyrolysis of $T / D$ mixtures

\begin{tabular}{llll}
\hline Sample name & $T / D=1 / 1$ & $T / D=2 / 1$ & $T / D=4 / 1$ \\
\hline$\%$ mass loss & 52.3 & 20.6 & 17.4 \\
\hline
\end{tabular}

$2 / 1$, and 4/1 were synthesized according to the procedure described in our previous papers [7, 18, 35]. To obtain glassy $\mathrm{SiCxOy}$, dried samples (xerogels) were subsequently heat-treated in a tube furnace at 200, 400, 600, 800, and $1000{ }^{\circ} \mathrm{C}$ temperature ranges under flowing argon atmosphere. To ensure oxygen-free environment, titanium shavings were used inside the furnace during pyrolysis process.

The middle infrared spectroscopy (MIR) studies were carried out to determine the structure of obtained materials. Standard KBr pallet method was used, and 128 scans were accumulated with resolution of $4 \mathrm{~cm}^{-1}$ in the range of 4000-400 $\mathrm{cm}^{-1}$ using Bruker VERTEX 70v spectrometer.

Thermogravimetric (TG) analysis was performed by the use of a Hi-Res TGA 2950 thermogravimetric analyzer 


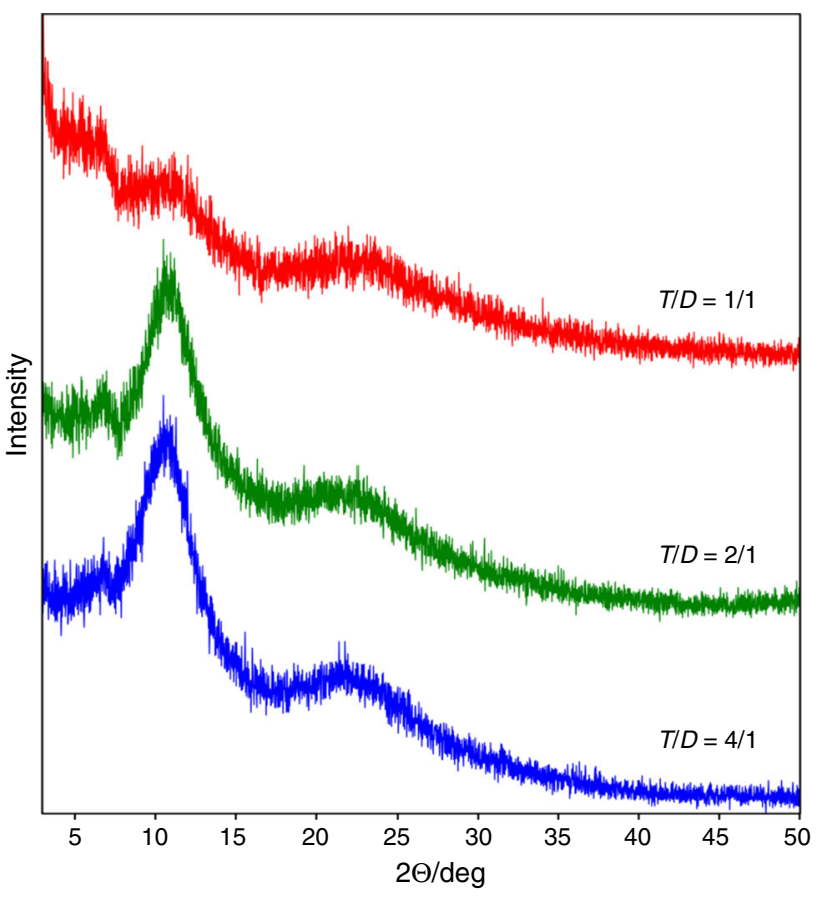

(TA Instruments) in argon atmosphere (heating rate $5 \mathrm{~K} \mathrm{~min}^{-1}$, resolution 3 , sensitivity 3 ).

SEM with EDX studies were carried out using FEI Europe Company Nova Nano SEM 200 with EDAX EDX attachment.

$\mathrm{X}$-ray powder diffraction measurements were done using Philips PANalytical X'Pert PRO MPD diffractometer. $\mathrm{Cu} \mathrm{K} \alpha 1$ line was used as radiation source and monochromatized by Ge (111) monochromator. Standard Bragg-Brentano geometry with $\Theta-2 \Theta$ setup was applied.

\section{Results and discussion}

Total mass loss, which can be determined as finished at about $1000{ }^{\circ} \mathrm{C}$ for all tested samples, is setting out as expected by the authors. With increase in number of $\mathrm{D}$ units within set mixtures, the thermogravimetric curve changes as well (Fig. 1). The least mass loss is observed for the least amount of $D$ units, mix $T / D=4 / 1$, while the most is registered for $T / D=1 / 1 \mathrm{mix}$ (Table 1 ).

Fig. 2 XRD patterns of obtained $T / D$ mixtures

(A)

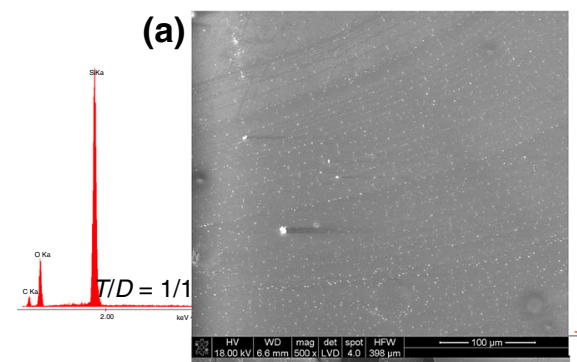

(b)

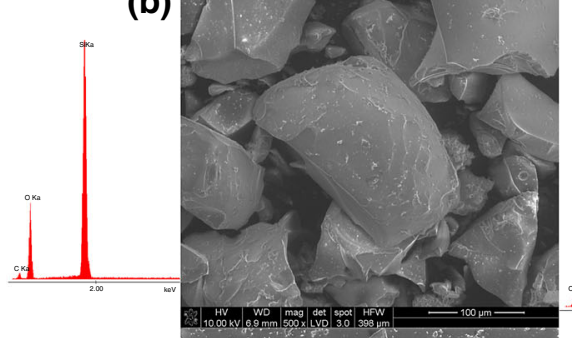

(c)

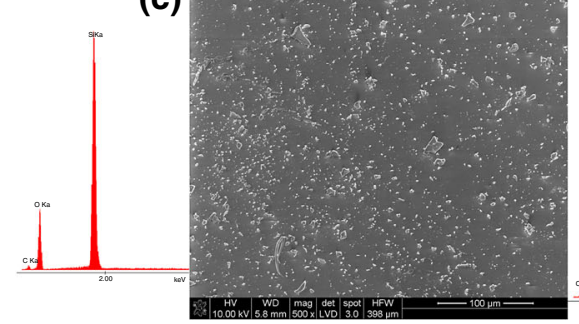

(B)
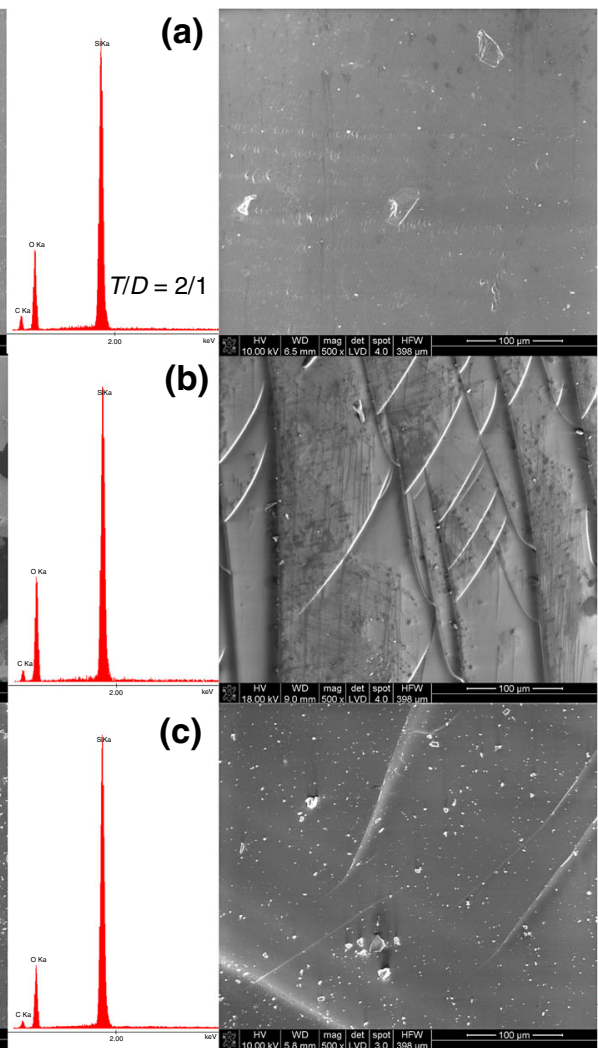

(C)
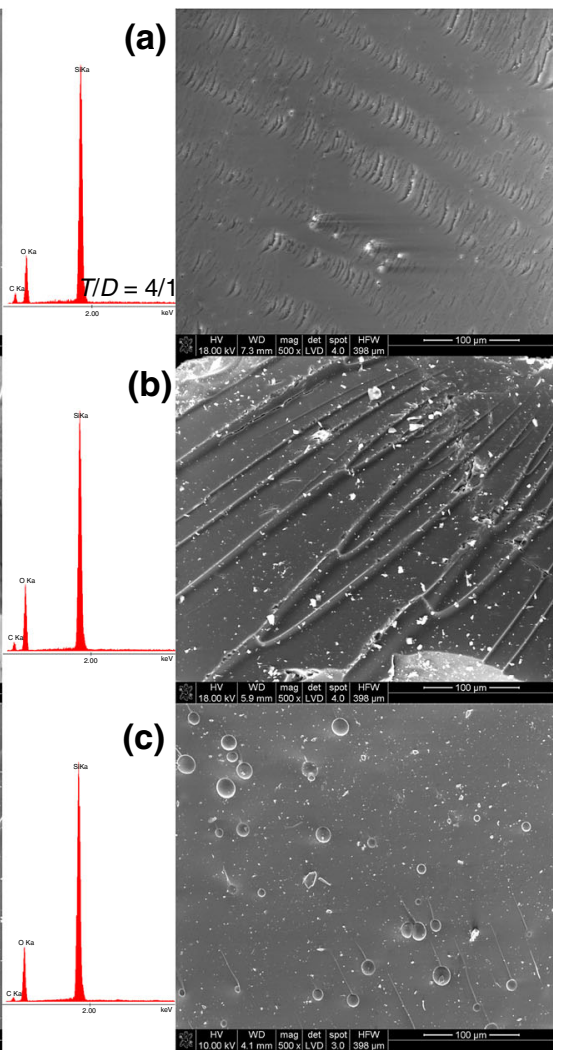

Fig. 3 SEM images and EDX spectra of $T / D=1 / 1, \mathbf{A} T / D=2 / 1, \mathbf{B}$ and $T / D=4 / 1, \mathbf{C}$ samples-a xerogel, samples pyrolyzed at $\mathbf{b} 800{ }^{\circ} \mathrm{C}$ and c $1000{ }^{\circ} \mathrm{C}$ 
Table 2 Chemical formula of tested $T / D$ mixtures after curing and pyrolysis in 800 and $1000{ }^{\circ} \mathrm{C}$

\begin{tabular}{|c|c|c|c|c|c|}
\hline Sample & Temperature & $\mathrm{C} / \mathrm{mass} \%$ & $\mathrm{O} / \mathrm{mass} \%$ & $\mathrm{Si} / \mathrm{mass} \%$ & Formula \\
\hline \multirow[t]{3}{*}{$T / D=1 / 1$} & Xerogel (RT) & 24.56 & 28.32 & 47.11 & $\mathrm{SiO}_{0,99} \mathrm{C}_{1,14}$ \\
\hline & $800{ }^{\circ} \mathrm{C}$ & 14.91 & 36.32 & 48.78 & $\mathrm{SiO}_{1,28} \mathrm{C}_{0,89}$ \\
\hline & $1000^{\circ} \mathrm{C}$ & 11.99 & 34.36 & 53.64 & $\mathrm{SiO}_{1,21} \mathrm{C}_{0,68}$ \\
\hline \multirow{3}{*}{$T / D=2 / 1$} & Xerogel (RT) & 24.36 & 32.73 & 42.91 & $\mathrm{SiO}_{1,14} \mathrm{C}_{1,30}$ \\
\hline & $800^{\circ} \mathrm{C}$ & 18.58 & 39.07 & 42.35 & $\mathrm{SiO}_{1,36} \mathrm{C}_{1,18}$ \\
\hline & $1000{ }^{\circ} \mathrm{C}$ & 17.35 & 30.5 & 52.14 & $\mathrm{SiO}_{1,07} \mathrm{C}_{0,87}$ \\
\hline \multirow[t]{3}{*}{$T / D=4 / 1$} & Xerogel (RT) & 21.99 & 31.12 & 46.89 & $\mathrm{SiO}_{1,09} \mathrm{C}_{1,12}$ \\
\hline & $800{ }^{\circ} \mathrm{C}$ & 20.61 & 34.41 & 44.98 & $\mathrm{SiO}_{1,20} \mathrm{C}_{1,16}$ \\
\hline & $1000^{\circ} \mathrm{C}$ & 12.87 & 33.39 & 53.74 & $\mathrm{SiO}_{1,17} \mathrm{C}_{0,71}$ \\
\hline
\end{tabular}

Fig. 4 MIR spectra of $T /$ $D=1 / 1$ samples A0-xerogel, A1-A5 pyrolized at 200,400 , 600 and $1000{ }^{\circ} \mathrm{C}$

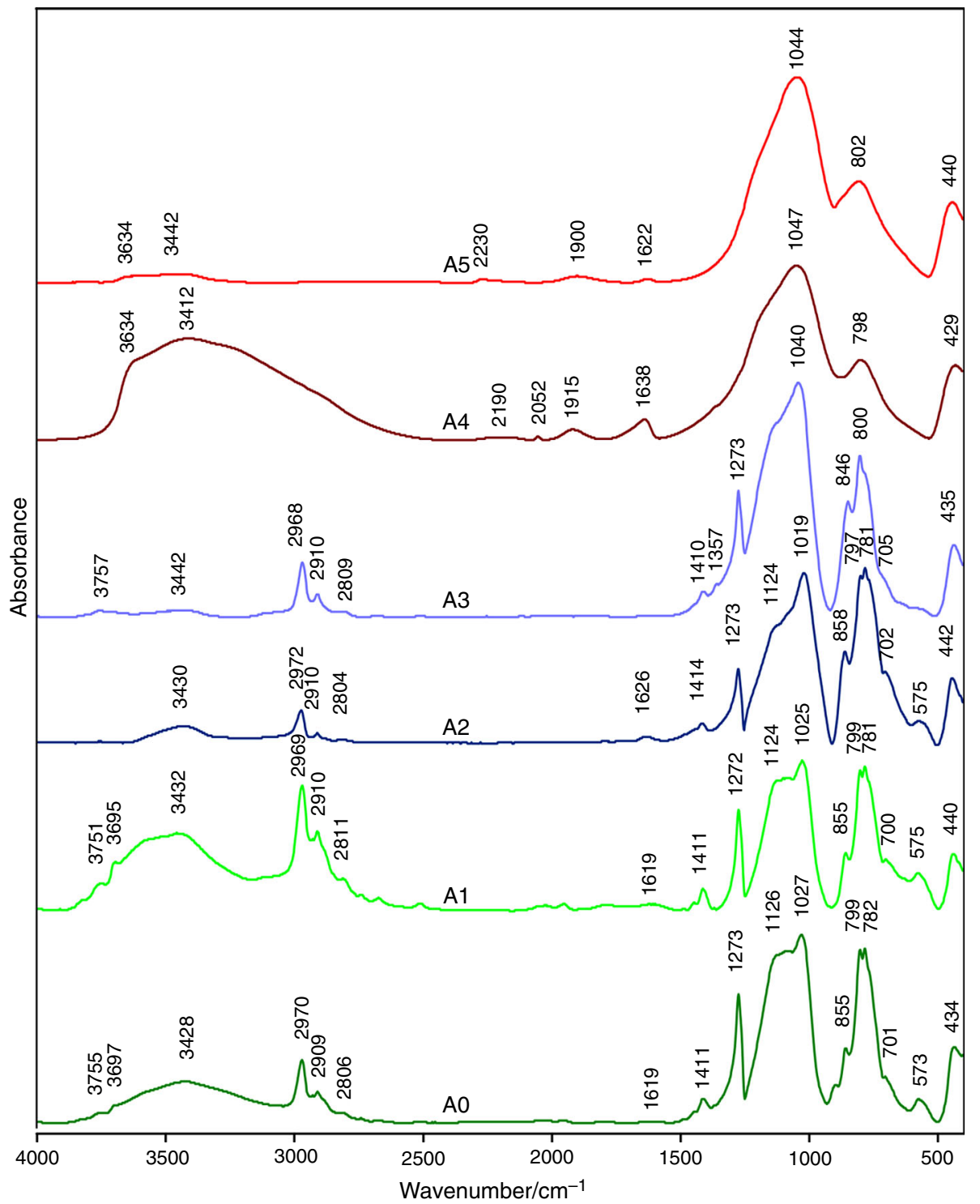




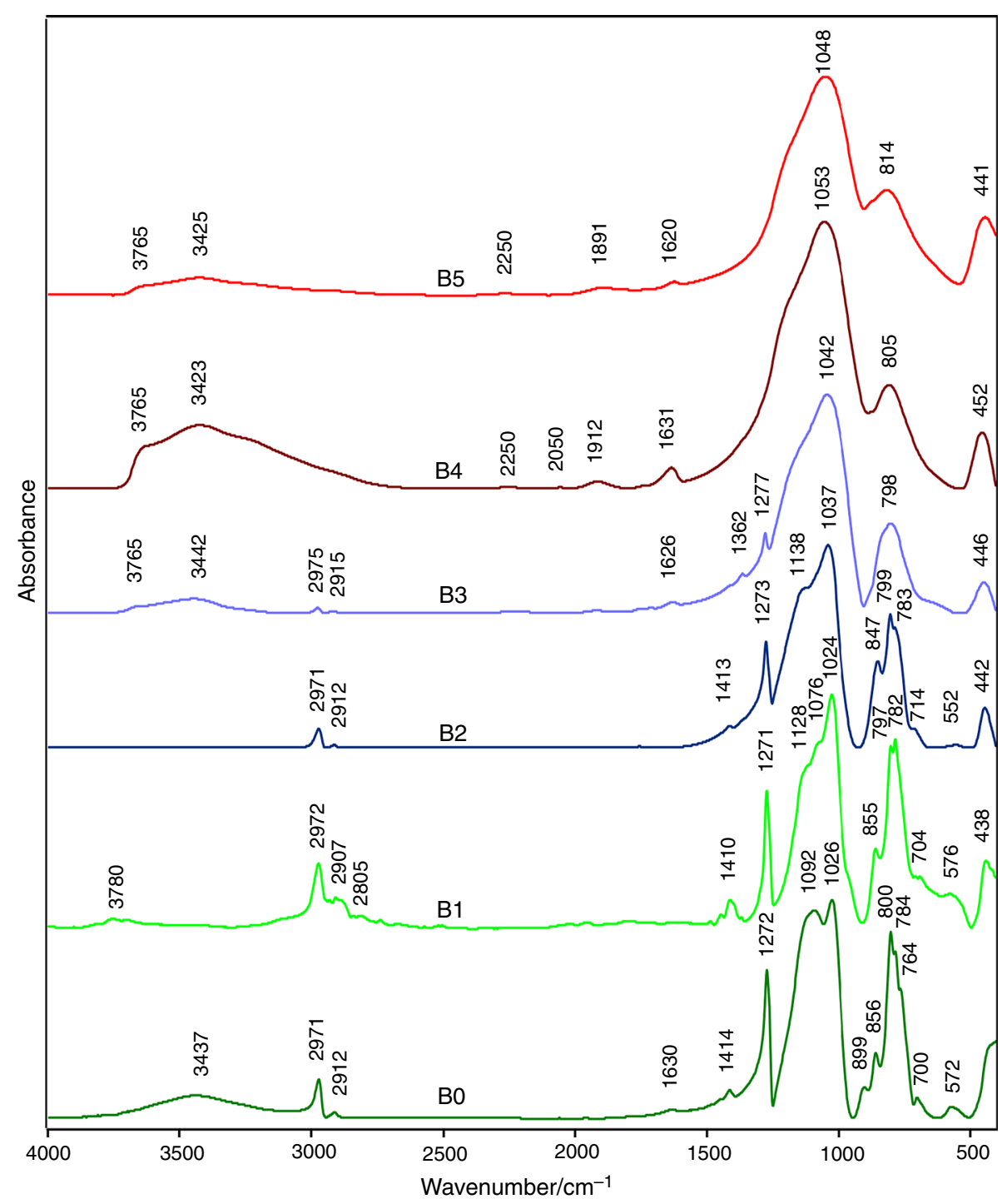

Fig. 5 MIR spectra of $T / D=2 / 1$ samples B0-xerogel, B1-B5 pyrolized at 200, 400, 600 and $1000{ }^{\circ} \mathrm{C}$

Most likely this is because that with increase in the number of $\mathrm{D}$ groups that are responsible for terminating ladder-like silsesquioxanes, obtained structures are getting shorter-lesser degree of condensation [19]. XRD studies seem to confirm this assumption. It is typical to receive two amorphous "halo" on diffraction patterns of ladder-like silsesquioxane samples (Fig. 2) [7, 8, 18]. Their presence, along with the conducted MIR studies (Figs. 4-6, samples A0, B0, C0), indicates well-defined ladder structure $[20,38]$. Silsesquioxane ladders, with their limited degree of order, especially with the chain-to-chain (intramolecular chain) distance give intensive reflection visible in the XRD pattern at approx. $10^{\circ} 2 \Theta$ (Fig. 2). Second halo, the broad one, can be attributed to intermolecular distance (intermolecular chain-to-chain thickness), or it can be the distance between the ladder structures $[20,38,39]$. In the case of xerogel $T / D=1 / 1$, first halo (approx. $10^{\circ}$ ) is poorly visible and has completely different shape and intensity from the rest of xerogels. This probably is due to the weaker ordering structure of this xerogel-the silsesquioxane ladders are shorter and disordered.

The first mass loss in the TG curve (Fig. 1) is observed at a temperature of approx. $200{ }^{\circ} \mathrm{C}$. With the decrease in the content of D units in the material, stronger shift toward higher temperatures are being observed (approx. $235{ }^{\circ} \mathrm{C}$ for $T / D=4 / 1$ ). It can be attributed to the release of cyclic D-oligomers that formed during the synthesis of ladder-like silsesquioxanes as a by-product. In addition, a mass loss associated with the release of residual solvent and $\mathrm{EtOH} /$ $\mathrm{H}_{2} \mathrm{O}$ from ongoing polycondensation reaction should be observed at this temperature [11, 14, 21, 44]. High impact on loss of mass in this area is the number of $\mathrm{D}$ groups in the 
Fig. 6 MIR spectra of $T /$ $D=4 / 1$ samples C0-xerogel, C1-C5 pyrolized at 200,400 , 600 and $1000{ }^{\circ} \mathrm{C}$

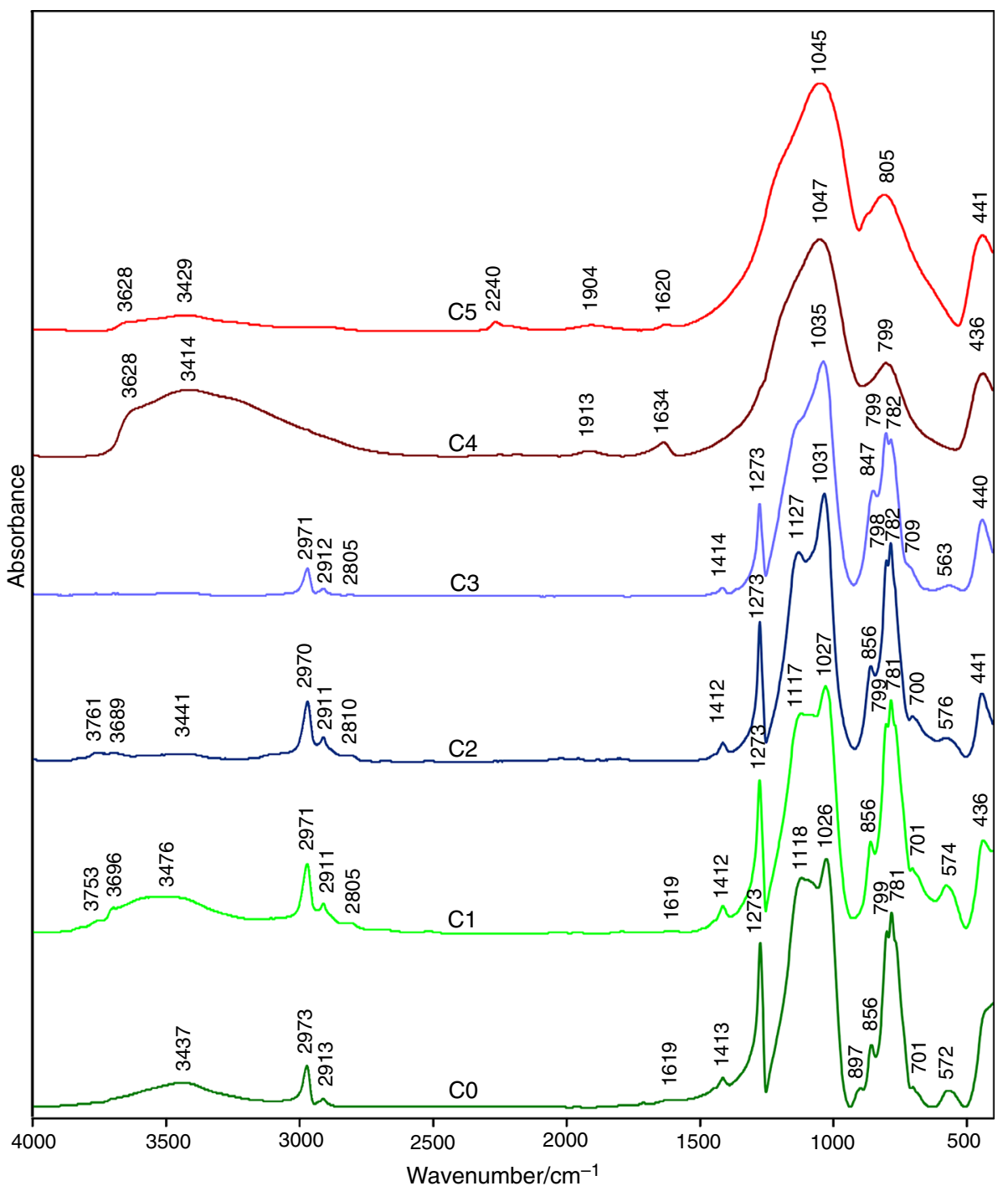

starting xerogel-it increases with the quantity (Fig. 1). Two less significant mass losses are observed for $T / D=2 /$ 1 sample at approx. 330 and $410{ }^{\circ} \mathrm{C}$. Minor mass loss at approx. $300{ }^{\circ} \mathrm{C}\left(290{ }^{\circ} \mathrm{C}\right.$ for $1 / 1,340{ }^{\circ} \mathrm{C}$ for $2 / 1$ and $350{ }^{\circ} \mathrm{C}$ for 4/1) most likely corresponds to elimination of branched $T / D$-oligomers formed during the synthesis [19, 21, 22]. Next loss is registered at 410 and $440{ }^{\circ} \mathrm{C}$ for $2 / 1$ and $1 / 1$ mix accordingly. It is responsible for the release of cyclic D-oligomers [19, 22-25]. Two high peaks on dTG curve for $T / D=2 / 1$ sample at approx. $580{ }^{\circ} \mathrm{C}$ can be linked with the process of depolymerization of short D chains [22], but authors think that its evenly possible for the sample to pop out of the platinum crucible during thermal analysis. It must be noted that crucibles were not sealed during the analysis process. It seems highly plausible because samples fired in temperatures exceeding $500{ }^{\circ} \mathrm{C}$ are characterized by drastically increased volume compared to starting xerogel volume (especially for $T / D=2 / 1$ mixture). It was observed for both partially fragmented and bulk samples. This implies rapid release of high amount of gases. It is peculiar in a way that we have not observed such extreme effect in the case of other $T / D$ mixtures. It can probably be attributed to the evolution of $\mathrm{H}_{2}$ and $\mathrm{CH}_{4}$ from the starting polymer-glass transition process $[11,19,26]$. Mass loss at approx. $600-700{ }^{\circ} \mathrm{C}$ can be assigned to further evolution of $\mathrm{D}$ units and gases originating from redistribution reaction of Si-O/Si-C bondings [19, 21-25, 44]. Release of $T$ units (oligomers), which based on TG and dTG curves is rising along the decrease in terminal $D$ groups, should still be present in this temperature range [22, 23]. At approx. $1000{ }^{\circ} \mathrm{C}$, no more mass loss is being observed.

SEM with EDX confirmed presence of $\mathrm{Si}, \mathrm{C}$, and $\mathrm{O}$ atoms in tested samples (Fig. 3). Chemical formulas were calculated for all the $T / D$ mixtures at room temperature 
(xerogel) and after pyrolysis at 800 and $1000{ }^{\circ} \mathrm{C}$ (Table 2). During the heating process amount of carbon is decreasing more rapidly the more $\mathrm{D}$ unites are introduced into xerogel. $T / D=2 / 1$ sample burned at $1000{ }^{\circ} \mathrm{C}$ is the closest to the stoichiometric composition. This confirms TG observations concerning the behavior of D terminal units.

Structural studies in the middle infrared range (MIR) were conducted for all the $T / D$ mixtures (Figs. 4-6). For the purpose of infrared studies, samples were named accordingly to notation: $T / D=1 / 1(\mathrm{~A}), 2 / 1(\mathrm{~B})$ and $4 / 1(\mathrm{C})$ - xerogel $(\mathrm{A}, \mathrm{B}, \mathrm{C}) 0,200{ }^{\circ} \mathrm{C}(\mathrm{A}, \mathrm{B}, \mathrm{C}) 1,400{ }^{\circ} \mathrm{C}(\mathrm{A}$, $\mathrm{B}, \mathrm{C}) 2,600{ }^{\circ} \mathrm{C}(\mathrm{A}, \mathrm{B}, \mathrm{C}) 3,800{ }^{\circ} \mathrm{C}(\mathrm{A}, \mathrm{B}, \mathrm{C}) 4,1000{ }^{\circ} \mathrm{C}(\mathrm{A}$, $\mathrm{B}, \mathrm{C}) 5$ (Figs. 4-6). All three xerogels have very similar spectra. Bands responsible for $\mathrm{CH}$ vibrations are very well visible on the xerogel spectra- $\mathrm{Si}-\left(\mathrm{CH}_{3}\right) \mathrm{x}$ bending vibrations are visible at $750-860 \mathrm{~cm}^{-1}$ range, and the $\mathrm{Si}-\mathrm{CH}_{3}$ and $\mathrm{Si}-\mathrm{C}_{2} \mathrm{H}_{5}$ stretching vibrations are visible at $1273 \mathrm{~cm}^{-1}$ (vs) and $1413 \mathrm{~cm}^{-1}$ (va) along with stretching vibrations of C-H groups at 2971 (va) and $2913 \mathrm{~cm}^{-1}$ (va) [7-9, 18, 20, 28, 29, 33, 34, 43, 45]. For A0 sample also $2800 \mathrm{~cm}^{-1}$ (vs) C-H band is visible [7, 28, 30]. The $\mathrm{Si}-\mathrm{OH}$ stretching bands at $3600-3800 \mathrm{~cm}^{-1}$ along with approx. $900 \mathrm{~cm}^{-1}$ bending vibration is visible, and therefore it can be concluded that the polycondensation process is not finished and the material will undergo further changes more easily during pyrolysis [7, 8, 18]. At approx. $1000-1200 \mathrm{~cm}^{-1}$ two bands are visible. The first one can be attributed to $v$ a vibrations of $\mathrm{Si}-\mathrm{O}-\mathrm{Si}$ (bridging) vibrations of ladder-like structure, while the other at around $1100 \mathrm{~cm}^{-1}$ is responsible for cage-like vibrations in ringlike structures of $\mathrm{Si}-\mathrm{O}-\mathrm{Si}$ ladder [7, 28, 30, 32, 34, 36, 37]. The $v$ s vibration of $\mathrm{Si}-\mathrm{O}-\mathrm{Si}$ bridges is visible in the range of approx. $550 \mathrm{~cm}^{-1}[7,8]$. The $\mathrm{Si}-\mathrm{C}_{3}$ vibration from the $\mathrm{Si}-\mathrm{CH}_{3}$ molecules can be observed at $700 \mathrm{~cm}^{-1}$ [21, 27, 30]. Based on the XRD analysis (Fig. 2), MIR studies, and theoretical calculations [40], it can be stated that obtained xerogels contain ladder-like silsesquioxane structures. As the temperature rises, materials start to undergo a series of changes. First one, at $200{ }^{\circ} \mathrm{C}$, is attributed to ongoing polycondensation reaction and release of water during this process, which can be seen as a broad band at approx. $3400 \mathrm{~cm}^{-1}$ on the $\mathrm{A} 1$ and $\mathrm{C} 1$ spectra (not visible for $\mathrm{B} 1$ sample). In addition the $\mathrm{CH}$ groups are becoming more intense and can suggest that more D-oligomers are being formed during this step. Samples burned at $400{ }^{\circ} \mathrm{C}(\mathrm{A}, \mathrm{B}, \mathrm{C} 2)$ exhibit gradual loss of all types of $\mathrm{CH}$ bands. Also water and $\mathrm{OH}$ bands are less visible. It is also worth to mention that during this step intensity of $\mathrm{Si}-\mathrm{O}-\mathrm{Si}$ band at $1100 \mathrm{~cm}^{-1}$ decreases, while the $440 \mathrm{~cm}^{-1}$ ( $\mathrm{Si}-\mathrm{O}$ bending mode) is starting to be more visible [18]. This confirms that during this step $T / D$-oligomers and D-oligomers, which are not involved into creation of glass structure, are being evaporated from the tested samples [19, 21].

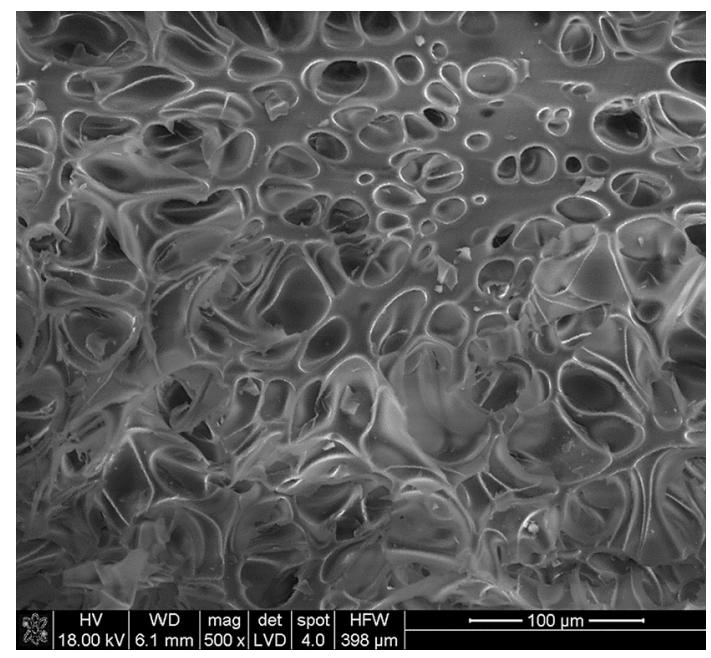

Fig. 7 SEM image of bulk $T / D=1 / 1$ sample after pyrolysis in $800{ }^{\circ} \mathrm{C}$ (A4 sample)

Similar situation is being observed for the samples fired at $600{ }^{\circ} \mathrm{C}$. Broadening of the $\mathrm{Si}-\mathrm{O}-\mathrm{Si}$ range and constant loss of intensity of $1100 \mathrm{~cm}^{-1}$ band indicates that the polymer to glass transition start to take place [7, 19, 21]. Additional OH groups that appear for A3 and B3 sample suggest that not all of volatile moistures are removed from the material and that the reorganization of the structure is still ongoing. Our previous studies showed that after pyrolysis at $800{ }^{\circ} \mathrm{C}$ obtained materials are black glasses [7, 8, 35] and look very similar. All three spectra contain a large band at 3410 and $1630 \mathrm{~cm}^{-1}$ which is attributed to the water present in the samples. If we compare these bands to $1040 \mathrm{~cm}^{-1}$ one, it is clearly visible that this ratio is lowest for A4 and highest for B4 sample. This is probably due to the high porosity of those samples (Fig. 7) and lack of hydrophobic $\mathrm{CH}_{3}$ groups (Figs. 4-6). Literature data state that a band at $1900 \mathrm{~cm}^{-1}$ can be a combinational band or a residual bonding of $-\mathrm{C} \equiv \mathrm{C}-$ specimen $[41,42]$. Bands at 2050 and $2230 \mathrm{~cm}^{-1}$ can be attributed to the $\mathrm{Si}-\mathrm{H}$ stretching vibrations ( $\mathrm{SiCSi}-\mathrm{H}$ and $\mathrm{O}_{3} \mathrm{Si}-\mathrm{H}$ groups) $[30,31,34]$. A, B, C5 samples (fired at $1000^{\circ} \mathrm{C}$ ) are much alike. Main band region at around $1040 \mathrm{~cm}^{-1}$ assigned to $\mathrm{Si}-\mathrm{O}-\mathrm{Si}$ asymmetric stretching vibrations (bridges) is a bit sharper compared to samples burned at $800{ }^{\circ} \mathrm{C}$. Small bands at 3410 and $1630 \mathrm{~cm}^{-1}$ remain but their presence can be attributed to both humidity in $\mathrm{KBr}$ and/or remnants of porosity and its absorbed water.

\section{Conclusions}

The aim of this work was to describe thermal evolution of different $T / D$ mixtures. Spectra recorded using MIR spectroscopy match the changes in TG curves for the tested 
samples. With the increase in amount of $D$ units introduced into xerogel structure dTG peaks shift to lower temperatures. This effect, the temperature shift of the decomposition of ladder-like structure, is also observed on the MIR spectra of all the mixtures. Furthermore, each $T / D$ mixture has its own dominant mechanism responsible for the mass loss. As it was described, despite the differences in TG curves and MIR spectra during heating process, final material—black glass—was achieved at $800{ }^{\circ} \mathrm{C}$ for all the tested mixtures.

Acknowledgements This work was supported by NCN project "Functional layers of black glasses based on ladder-like silsesquioxanes 2014/15/B/ST8/02827."

Open Access This article is distributed under the terms of the Creative Commons Attribution 4.0 International License (http://creativecommons. org/licenses/by/4.0/), which permits unrestricted use, distribution, and reproduction in any medium, provided you give appropriate credit to the original author(s) and the source, provide a link to the Creative Commons license, and indicate if changes were made.

\section{References}

1. Brus J, Kolar F, Machovic V, Svitilova J. Structure of silicon oxycarbide glasses derived from poly(methylsiloxane) and poly[methyl(phenyl)siloxane] precursors. J Non-Cryst Solids. 2001;289:62-74.

2. Moysan C, Riedel R, Harshe R, Rouxel T, Augereau F. Mechanical characterization of a polysiloxane-derived SiOC glass. J Eur Ceram Soc. 2007;27:397-403.

3. Halasova M, Chlup Z, Strachota A, Cerny M, Dlouhy I. Mechanical response of novel SiOC glasses to high temperature exposition. J Eur Ceram Soc. 2012;32:4489-95.

4. Colón-Santana JA, Echeverría-Mora E, Price L, Balerio T, Shao L, Nastasi M. Synthesis, thermal stability and the effects of ion irradiation in amorphous $\mathrm{Si}-\mathrm{O}-\mathrm{C}$ alloys. Nucl Instrum Methods B. 2015;350:6-13.

5. Lu K, Li J. Fundamental understanding of water vapor effect on SiOC evolution during pyrolysis. J Eur Ceram Soc. 2016;36:411-22.

6. Saha A, Raj R, Williamson DL. A model for the nanodomains in polymer-derived SiCO. J Am Ceram Soc. 2006;89:2188-95.

7. Jeleń P, Bik M, Nocuń M, Gawęda M, Długoń E, Sitarz M. Free carbon phase in SiOC glasses derived from ladder-like silsesquioxanes. J Mol Struct. 2016;1126:172-6.

8. Sitarz M, Czosnek C, Jeleń P, Odziomek M, Olejniczak Z, Kozanecki M, Janik JF. SiOC glasses produced from silsesquioxanes by the aerosol-assisted vapor synthesis method. Spectrochim Acta A. 2013;112:440-5.

9. Kwang-Man L, Chang-Young K, Chi-Kyu C, Navamathavan R. Characteristics of $\mathrm{SiOC}(-\mathrm{H})$ thin films prepared by using plasma-enhanced atomic layer deposition. J Korean Phys Soc. 2011;59:3074-9.

10. Sang-Yong K. Characterization of ultra low-k $\operatorname{SiOC}(\mathrm{H})$ film deposited by plasma-enhanced chemical vapor deposition (PECVD). Trans Electr Electron Mater. 2012;13:69-72.

11. Strachota A, Černý M, Chlup Z, Šlouf M, Hromádková J, Pleštil J, Šandová H, Glogar P, Sucharda Z, Havelcová M, Schweigstillová J, Dlouhý I, Kozák V. Optimization of sol-gel/pyrolysis routes to silicon oxycarbide glasses. J Non-Cryst Solids. 2012;358:2771-82.
12. Yamamoto K, Ohshita J, Mizumo T, Tsuru T. Efficient synthesis of SiOC glasses from ethane, ethylene, and acetylene-bridged polysilsesquioxanes. J Non-Cryst Solids. 2015;408:137-41.

13. Chunqing L, Yang L, Zhongrong S, Ping X, Daorong D, Rongben $\mathrm{Z}$, Chaobin H, Taisheng C. Synthesis and characterization of novel alcohol-soluble ladderlike poly(silsesquioxane)s containing side-chain hydroxy groups. Macromol Chem Phys. 2001;202:1576-80.

14. Burns GT, Taylor RB, Xu Y, Zangvi A, Zank GA. High-temperature chemistry of the conversion of siloxanes to silicon carbide. Chem Mater. 1992;4:1313-23.

15. Gao F, Zhang L, Tang L, Zhang J, Zhou Y, Huang F, Du L. Synthesis and properties of arylacetylene resins with siloxane units. Bull Korean Chem Soc. 2010;31:976-80.

16. Liu X, Xie K, Zheng Ch, Wang J, Jing Z. Si-O-C materials prepared with a sol-gel method for negative electrode of lithium battery. J Power Sour. 2012;214:119-23.

17. Zhuo R, Colombo P, Pantano C, Vogler EA. Silicon oxycarbide glasses for blood-contact applications. Acta Biomater. 2005;1:583-9.

18. Sitarz M, Jastrzębski W, Jeleń P, Długoń E, Gawęda M. Preparation and structural studies of black glasses based on ladder-like silsesquioxanes. Spectrochim Acta A. 2014;132:884-8.

19. Trimmel G, Badheka R, Babonneau F, Latournerie J, Dempsay P, Bahloul-Houlier D, Parmentier J, Soraru GD. Solid state NMR and TG/MS study on the transformation of methyl groups during pyrolysis of preceramic precursors to SiOC glasses. J Sol-Gel Sci Technol. 2003;26:279-83.

20. Handke M, Handke B, Kowalewska A, Jastrzębski W. New polysilsesquioxane materials of ladder-like structure. J Mol Struct. 2009;924-926:254-63.

21. Brequel H, Parmentier J, Walter S, Badheka R, Trimmel G, Masse S, Latournerie J, Dempsey P, Turquat C, DesmartinChomel A, Le Neindre-Prum L, Jayasooriya UA, Hourlier D, Kleebe H-J, Soraru GD, Enzo S, Babonneau F. Systematic structural characterization of the high-temperature behavior of nearly stoichiometric silicon oxycarbide glasses. Chem Mater. 2004;16:2585-98.

22. Havelcová M, Strachota A, Cerny M, Sucharda Z, Slouf M. Effect of the dimethylsilyloxy co-monomer " $D$ " on the chemistry of polysiloxane pyrolysis to SiOC. J Anal Appl Pyrol. 2016;117:30-45.

23. Brus J, Kolar F, Machovic V, Svitlova J. Structure of silicon oxycarbide glasses derived from poly(methylsiloxane) and poly[methyl(phenyl)siloxane] precursors. J Non-Cryst Solids. 2011;289:62-74.

24. Strachota A, Černý M, Glogar P, Sucharda Z, Havelcová M, Chlup Z, Dlouhý I, Kozák V. Preparation of silicon oxycarbide composites toughened by inorganic fibers via pyrolysis of precursor siloxane composites. Acta Phys Polon, A. 2011;120:326-30.

25. Radovanovic E, Gozzi MF, Goncalves MC, Yoshida IVP. Silicon oxycarbide glasses from silicone networks. J Non-Cryst Solids. 1999;248:37-48.

26. Hurwitz FI, Heimann P, Farmer SC, Hembree DM Jr. Characterization of the pyrolytic conversion of polysilsesquioxanes to silicon oxycarbides. J Mater Sci. 1993;28:6622-30.

27. Enríquez E, Fernández JF, de la Rubia MA. Highly conductive coatings of carbon black/silica composites obtained by a sol-gel process. Carbon. 2012;50:4409-17.

28. Navamathavan R, Kim CY, Jung AS, Choi CK, Lee HJ. Deposition and characterization of porous low-dielectric-constant $\mathrm{SiOC}(-\mathrm{H})$ thin films deposited from TES/O2 precursors by using plasma-enhanced chemical vapor deposition. J Korean Phys Soc. 2008;53:351-6. 
29. Oh T, Kim CH, Jung CS. Relationship between the binding energy and boundary condition in SiOC film for ILD application. GDC. 2011;261:213-8.

30. Segatelli MG, Nunes Pires AT, Yoshida IVP. Synthesis and structural characterization of carbon-rich $\mathrm{SiCxOy}$ derived from a Ni-containing hybrid polymer. J Eur Ceram Soc. 2008;28:2247-57.

31. Dřínek V, Bastl Z, Šubrt J, Yabe A, Pola J. IR laser-induced reactive ablation of silicon monoxide in hydrogen and water atmosphere. J Mater Chem. 2002;12:1800-5.

32. Ward LJ, Schofield WCE, Badyal JPS, Goodwin AJ, Merlin PJ. Atmospheric pressure glow discharge deposition of polysiloxane and SiOx films. Langmuir. 2003;19:2110-4.

33. Yun S, Luo H, Gao Y. Superhydrophobic silica aerogel microspheres from methyltrimethoxysilane: rapid synthesis via ambient pressure drying and excellent absorption properties. RSC Adv. 2014;4:4535-42.

34. Sorarù GD, Karakuscu A, Boissiere C, Babonneau F. On the shrinkage during pyrolysis of thin films and bulk components: the case of a hybrid silica gel precursor for SiOC glasses. J Eur Ceram Soc. 2012;32:627-32.

35. Handke M, Sitarz M, Długoń E. Amorphous SiCxOy coatings from ladder-like polysilsesquioxanes. $\mathrm{J}$ Mol Struct. 2011;993:193-7.

36. Sitarz M. The structure of simple silicate glasses in the light of Middle Infrared spectroscopy studies. J Non-Cryst Solids. 2011;357:1603-8.

37. Lubas M, Sitarz M, Fojud Z, Jurga S. Structure of multicomponent $\mathrm{SiO}_{2}-\mathrm{Al}_{2} \mathrm{O}_{3}-\mathrm{Fe}_{2} \mathrm{O}_{3}-\mathrm{MgO}$ glasses for preparation of fibrous insulating materials. J Mol Struct. 2005;744-747:615-9.
38. Handke M, Jastrzębski W, Kowalewska A, Mozgawa W. Spectroscopic study of preceramic polymers (xerogels) obtained by hydrolytic condensation of ethoxycyclosiloxanes. J Mol Struct. 2009;924-926:248-53.

39. Choi S-S, Lee AS, Lee HS, Jeon HY, Baek K-Y, Choi DH, Hwang SS. Synthesis and characterization of UV-curable ladderlike polysilsesquioxane. J Polym Sci A Polym Chem. 2011;49:5012-8.

40. Szczypka W, Jeleń P, Koleżyński A. Theoretical studies of bonding properties and vibrational spectra of chosen ladder-like silsesquioxane clusters. J Mol Struct. 2014;1075:599-604.

41. Ypenburg JW, Gerding H. Vibrational spectra and structure(s) of $\mathrm{X}(\mathrm{OR})$, molecules with $\mathrm{X}=\mathrm{C}, \mathrm{Si}$ and $\mathrm{R}=$ methyl, ethyl. Recl Trav Chim Pays-Bas. 1972;91:1245-74.

42. Konshina EA (2016) Amorphous hydrogenated carbon films with diamond-like and polymer-like properties, 2016; crystalline and non-crystalline solids, Dr. Pietro Mandracci (Ed).

43. Ermakova EN, Sysoev SV, Nikolaev RE, Nikulina LD, Lis AV, Tsyrendorzhieva IP, Rakhlin VI, Plyusnin PE, Kosinova ML. Thermal properties of some organosilicon precursors for chemical vapor deposition. J Therm Anal Calorim. 2016;126:609-16.

44. Jitianu A, Lammers K, Arbuckle-Kiel G-A, Klein L-C. Thermal analysis of organically modified siloxane melting gels. J Therm Anal Calorim. 2012;107:1039-45.

45. Sarada K, Muraleedharan K. Thermal degradation and optical properties of SiC-infused polystyrene nanocomposites. J Therm Anal Calorim. 2016;126:1809-19. 